\title{
Peran E-commerce dalam Meningkatkan Resiliensi Bisnis diera Pandemi
}

\author{
Mohammad Orinaldi \\ Universitas Islam Negeri Sultan Thaha Syaifuddin Jambi \\ orinaldi@uinjambi.ac.id
}

\begin{abstract}
Online business based on E-commerce has long been known since before the Covid-19 pandemic, as evidenced by $15.08 \%$ of business people have used digital platforms in developing their businesses. E-commerce is a public need that has increased drastically during the Covid-19 pandemic. E-commerce platform users increased by $38.3 \%$ as long as social policies were implemented. This study aims to analyze the role of E-commerce in maintaining business during an economic recession. The research method used is literature review. The results of the discussion show that the types of small businesses and MSMEs are sectors that are quite affected by Covid-19. The business sector will not be able to survive a period of economic recession if it does not adapt to technological developments towards the online market. E-commerce is key in the creation of an online market, so that it can mediate interactions between producers or sellers and consumers. E-commerce can maintain a balance of production and consumption because trading activities are maintained over a long distance. This balance can encourage economic growth in a more positive direction. E-commerce is able to help business actors to maintain their business activities, as well as to help consumers maintain purchasing power to meet their needs.
\end{abstract}

Keywords: E-commerce, Economic Recession, Business, Pandemic Covid19

\section{PENDAHULUAN}

Pertumbuhan ekonomi positif yang relatif meningkat selalu diupayakan oleh suatu negara termasuk Indonesia. Tren positif dalam pertumbuhan ekonomi menjadi salah satu indikator keberhasilan atas implementasi kebijakan-kebijakan dalam perekonomian. Upaya-upaya yang dilakukan oleh pemerintah guna mendorong laju pertumbuhan 
ekonomi pada dasarnya berorientasi pada peningkatan pendapatan nasional dengan meningkatkan mutu faktor-faktor produksi negara yang bersangkutan. Upaya menjaga laju pertumbuhan ekonomi juga sebagai langkah agar tidak memicu krisis yang menggerus maupun menumbangkan perekonomian. Pertumbuhan ekonomi memiliki makna sebagai kenaikan PDB atau PNB riil negara pada tahun tertentu jika dibandingkan dengan tahun-tahun sebelumnya (Sukirno, 2006). Hal ini menunjukkan bahwa pertumbuhan ekonomi merefleksikan perubahan ekonomi dalam jangka panjang melalui kenaikan pendapatan penduduk secara perlahan. Eksistensi E-commerce sebelum pandemi Covid-19 dapat dilihat dalam Gambar 2. berikut ini;

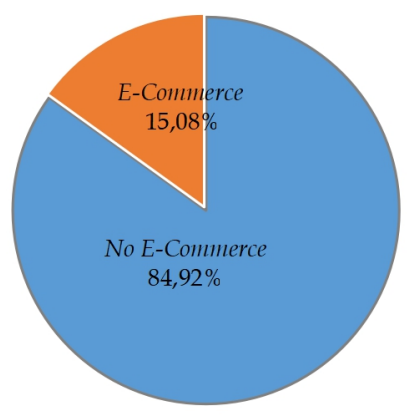

Sumber: BPS “Statistik E-commerce 2019"

Gambar 1. Persentase Usaha dengan E-commerce di Indonesia

Berdasarkan data di atas terlihat memang kebanyakan pelaku usaha di Indonesia masih terpaku dengan sistem konvensional. Hasil survei yang dilakukan oleh BPS juga menunjukkan bahwa sebanyak $84,92 \%$ pelaku usaha masih belum menggunakan E-commerce dengan berbagai alasan. Survei BPS menunjukkan bahwa sebanyak 70,89\% pelaku usaha lebih nyaman berjualan secara langsung (offline). Ketidaktertarikan pelaku usaha menggunakan E-commerce menjadi alasan nomor dua dengan hasil survei sebanyak 42,52\%. Adapun kurangnya pengetahuan akan digital marketing dengan menempati alasan urutan ketiga dengan hasil survei 21,78\%. Hasil survei BPS tersebut dapat dijadikan rujukan yang menunjukkan alasan mendasar kegagalan usaha terutama bagi pelaku usaha yang akhirnya gulung tikar akibat tidak mau beradaptasi dengan perubahan keadaan. 


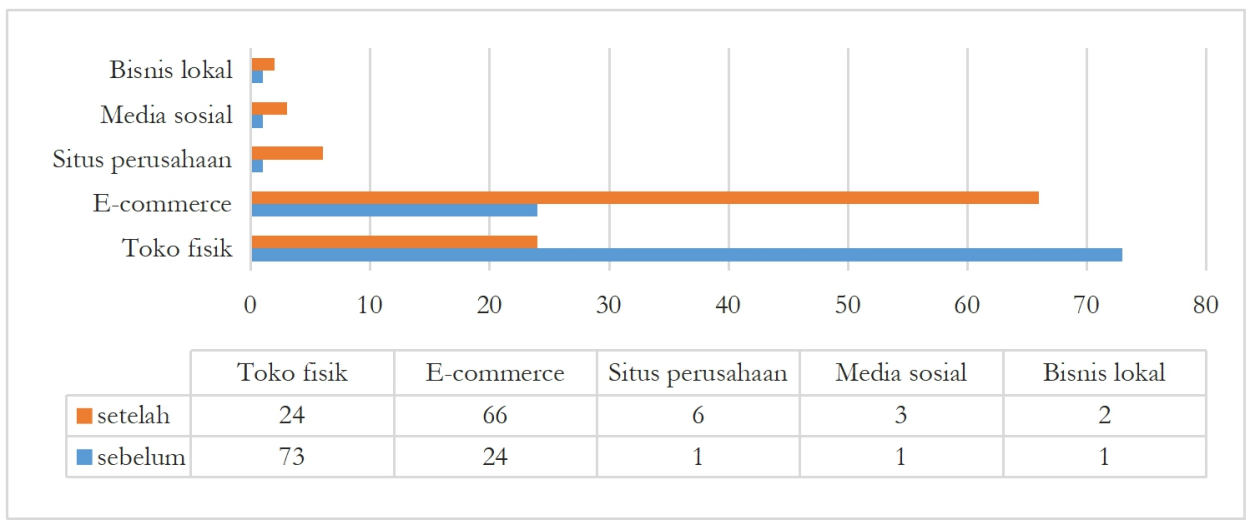

Sumber: databoks.katadata.co.id

Gambar 2. Pembelian produk non-makanan setelah dan sebelum pandemi Covid-19

Berdasarkan data pada Gambar 3. terlihat bahwa terjadi penurunan signifikan dari toko fisik (offline) dari sebelum pandemi hingga setelah pandemi berlangsung. Begitu juga sebaliknya terjadi peningkatan pada transaksi dengan basis digital (online) terutama pada platform E-commerce. Hal ini semakin menunjukkan bahwa tren peningkatan pengguna E-commerce selama pandemi telah meningkat drastis. E-commerce sebelum pandemi Covid-19 merupakan sebuah pilihan, namun di masa sekarang penggunaan E-commerce seperti sebuah keharusan bagi produsen agar tetap mempertahankan bisnis mereka (Sudaryono et al, 2020). Pergeseran kebiasaan tersebut harus direspon dengan baik dan hati-hati agar memberikan kebermanfaatan baik bagi produsen maupun konsumen terutama saat Indonesia menghadapi dampak resesi ekonomi.

Perlambatan pertumbuhan ekonomi secara nasional menunjukkan bahwa kegiatan produksi dan ekonomi terganggu bahkan berkurang. Penurunan laju pertumbuhan juga menyebabkan rentetan permasalahan baru seperti pengangguran hingga peningkatan angka kemiskinan. Adapun dampak Covid-19 saat ini juga menyasar sektor perekonomian Indonesia yang mengakibatkan lonjakan pengangguran hingga angka kemiskinan. Ketidaksiapan masyarakat atas situasi serba dibatasi semakin mempersulit keadaan perekonomian. Bahkan sejak kuartal pertama tahun 2020 telah memperlihatkan adanya pelambatan 
pertumbuhan. Hal ini wajar terjadi mengingat lima negara di kawasan utama dunia (Tiongkok, Amerika Serikat, Jepang, India, dan Uni Eropa) mengalami perlambatan pergerakan ekonomi secara global pada 2020 akibat munculnya kasus Covid-19, kebijakan ekonomi populis, hingga penurunan indeks harga komoditas (Damuri \& Hirawan 2020). Adapun dampak yang semakin tidak terkendali dalam perekonomian selama pandemi terus menekan kekuatan perekonomian dunia, bahkan tren pertumbuhan ekonomi yang semakin menurun hingga mencapai nilai negatif semakin mendorong ancaman resesi bagi perekonomian diberbagai negara.

Berdasarkan uraian yang telah dipaparkan makan penulis tertarik untuk mengetahui sejauh mana dampak Covid-19 terhadap resesi ekonomi dan imbasnya pada peningkatan pengguna E-commerce di Indonesia. Tujuan penelitian ini adalah untuk menganalisis peran Ecommerce sebagai bagian dari upaya pemuliahan ekonomi nasional dalam masa resesi ekonomi sekaligus sebagai upaya pelaku usaha untuk mempertahankan usaha sesuai dengan tuntutan perkembangan digital di era 4.0. Hasil penelitian diharapkan dapat memberikan rekomendasi positif bagi pelaku usaha terkait dengan pentingnya mempertahankan usahanya melalui digital marketing.

\section{TINJAUAN PUSTAKA}

Perlambatan pertumbuhan ekonomi menuju resesi semakin memperburuk kondisi dunia usaha. Semenjak kebijakan pembatasan sosial berskala besar hingga masa new normal menyebabkan hampir seluruh usaha terimbas dampak Covid-19. Bahkan sektor-sektor industri dengan sistem padat karya terpaksa mengurangi karyawan dan beban produksi agar tetap bertahan di masa pandemi. Hal ini ditegaskan oleh Taufik dan Ayuningtyas (2020) bahwa pandemi Covid-19 telah menyebabkan economic shock yang memengaruhi ekonomi negara baik dalam skala lokal, nasional hingga internasional dan mengganggu jalannya usaha baik usaha perseorangan, usaha mikro, usaha kecil maupun usaha dalam skala menengah dan besar.

Sektor usaha mikro menerima dampak cukup berat sejak Covid19 mulai mewabah di Indonesia. Meskipun sektor tersebut pada masa 
krisis ekonomi mampu bertahan dan tetap eksis nyatanya laju perkembangan zaman telah merubah paradigma tersebut. Pembatasan interaksi sosial masyarakat secara drastis memengaruhi penerimaan atau omset usaha kecil menengah. Hal ini dikarenakan sistem konvensional masih sangat diandalkan dalam jenis usaha tersebut. Menurut Rofiq dkk (2020) kebijakan atau peraturan pembatasan sosial yang ditetapkan oleh pemerintah cenderung mengurangi proses transaksi antarmuka. Hal ini menggambarkan secara jelas bahwa sektor-sektor industri kecil termasuk UMKM cukup terdampak dengan adanya Covid-19 mengingat sektorsektor tersebut masih megandalkan hubungan atau interaksi secara langsung. Sistem tersebut memang terbukti ampuh membuat industri tersebut tetap bertahan pada krisis ekonomi 1998, namun pada saat ini sistem tersebut kurang relevan dan terpaksa tumbang akibat pembatasan interaksi dan kerumunan yang ditetapkan oleh pemerintah. Akibatnya tanpa inovasi terbarukan maka eksistensi UMKM mulai meredup bahkan gulung tikar karena tidak dapat melakukan penjualan seperti sebelumnya. Ketidakmampuan sektor-sektor tertentu untuk beradaptasi akan kebijakan pembatasan sosial bahkan telah menyebabkan banyak usaha terancam gulung tikar.

Pelaku usaha perlu mempertimbangkan untuk membuka tokotoko online atau dengan kata lain berbisnis dengan menerapkan sistem digital marketing. Penerapan digital mareketing dilakukan untuk menyesuaikan dengan tuntutan perkembangan teknologi 4.0 sekaligus sebagai upaya meningkatkan promosi maupun pemasaran produk dan jasa yang ditawarkan. Menurut Rofiq et. al (2020) keberadaan digital marketing mampu membuka peluang dan meluaskan pangsa pasar yang sebelumnya terbatas pada jarak, waktu, dan cara komunikasi. Kemudahan akses internet yang saat ini juga dirasakan oleh masyarakat Indonesia menjadi penyokong agar digital marketing berjalan dengan lancar. Apabila implementasi digital marketing berjalan dengan lancar maka tentu akan mempermudah proses transaksi dan tentunya juga mampu meningkatkan volume penjualan. Digital marketing juga menjadi strategi jitu yang dapat dipilih oleh pelaku usaha di masa pandemi Covid-19 . Pembatasan jarak dan interaksi dapat diatasi dengan sistem 
pemasaran tersebut, sehingga usaha-usaha tetap dapat bertahan meskipun tanpa adanya interaksi langsung dengan pelanggan.

Sistem digital marketing dapat ditunjukkan dalam pengembangan bisnis dengan basis E-commerce. Keberadaan platform E-commerce menjadi kebutuhan utama publik selama pandemi karena takut untuk melakukan kegiatan berbelanja secara langsung (Sudaryono dkk, 2020). E-commerce sudah cukup lama berkembang di Indonesia dan dimanfaatkan oleh berbagai kalangan baik untuk memenuhi kebutuhan maupun berjualan untuk meningkatkan omset dengan basis online. E-commerce menjadi wadah bagi digital marketing yang sejatinya telah cukup mampu menarik banyak konsumen di Indonesia bahkan jauh sebelum wabah Covid-19 menginfeksi Indonesia. Menurut Sudaryono et. al (2020) pada tahun 2019 E-commerce telah mendorong Indonesia menjadi negara dengan nilai ekonomi digital terbesar di Asia Tenggara hingga $\$ 40$ miliar bahkan pada tahun 2025 nilai tersebut dipresisikan meningkat menjadi \$130 miliar.

Berdasarkan data yang dihimpun pada Gambar 3. dibawah ini terlihat bahwa pertumbuhan ekonomi Indonesia pada kuartal I tahun 2020 berada pada $2,97 \%$ yoy (year on year), adapun pada kuartal ke II ekonomi Indonesia mengalami kontraksi hingga $-5,32 \%$ yoy.

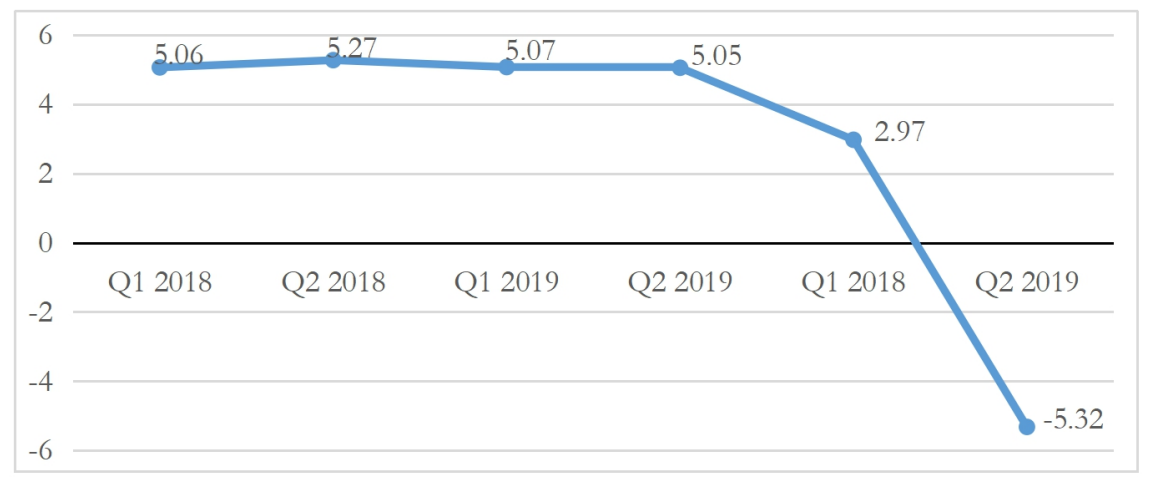

Sumber: Badan Pusat Statistik (diolah 2020)

Gambar 3. Grafik Pertumbuhan Ekonomi Indonesia Kuartal I \& II 20182020

Hal ini menunjukkan bahwa terdapat perlambatan pertumbuhan ekonomi dari kuartal pertama hingga kuartal kedua. Perlambatan laju pertumbuhan tersebut tentunya dapat memengaruhi kualitas kesejahteraan masyarakat Indonesia dengan meningkatnya angka 
pengangguran dan kemiskinan. Bahkan Bappenas memprediksi bahwa tahun 2020 akan terjadi lonjakan angka pengangguran hingga 4-5 juta orang atau tembus hingga 11 juta pengangguran per tahun 2020 (Kompas.com, 2020). Permasalahan dapat berdampak luas hingga dapat menyebabkan penurunan produktivitas tenaga kerja bahkan mendorong munculnya konflik sosial hingga politik di lingkungan masyarakat. Resesi juga menjadi masalah yang harus dihadapi oleh perekonomian Indonesia setelah dikuartal ketiga pertumbuhan ekonomi berada pada -1 hingga $-2,9 \%$ yoy. Meskipun lebih baik daripada kuartal kedua, Indonesia tetap harus berusaha keluar dari gerak negatif pertumbuhan ekonomi tersebut agar tidak terjebak pada dampak resesi yang berkepanjangan.

Platform E-commerce baik dalam skala nasional hingga lokal terus bermunculan dan semakin diminati oleh konsumen. Banyak konsumen yang beralih ke toko online semakin mendorong penjual harus bertransformasi juga menuju digitalisasi kegiatan transaksi. Adanya Covid-19 yang mematikan transaksi langsung usaha membuka kesempatan lai bagi usaha dengan pemanfaatan E-commerce. Berdasarkan statistik menunjukkan bahwa pengguna E-commerce semakin meningkat selama pandemi Covid-19 dibuktikan dengan meningkatnya traffic pengguna E-commerce selama masa pandemi.

Keberadaan Covid-19 saja sudah cukup membuat perekonomian pelaku usaha kecil maupun UMKM terbebani. Demikian halnya ditambah dengan resesi ekonomi yang saat ini dihadapi oleh Indonesia. Optimalisasi E-commerce dapat menjadi alternatif untuk meningkatkan daya saing produk dan daya beli masyarakat sehingga kelesuan di bidang ekonomi tidak semakin berlarut. Namun demikian semakin tinggi penggunaan media digital selalu disertai dengan dampak positif dan negatif yang harus dimitigasi bersama baik oleh pemerintah, pelaku usaha, maupun konsumen itu sendiri.

\section{METODE PENELITIAN}

Penulisan artikel ini menggunakan pendekatan kualitatif. Adapun metode penelitian menggunakan kajian pustaka (literature review) berkaitan dengan tren peningkatan E-commerce dan resesi ekonomi di 
Indonesia akibat Covid-19. Kajian kepustakaan dilakukan dengan tahapan yang mencakup proses identifikasi, evaluasi, dan sintesis. Proses identifikasi mencakup gambaran definisi ruang lingkup penelitian melalui identifikasi dari sumber-sumber yang relevan, proses evaluasi mencakup review terhadap temuan terdahulu, adapun proses sintesis dilakukan dengan menuliskan review sesuai dengan aplikasi studi yang dilakukan. Penyusunan artikel juga menggunakan metode analisis isi dalam analisis data penelitian yang bertujuan untuk menganalisa data penelitian secara mendalam berkaitan dengan sumber informasi tertulis maupun cetak dalam media masa. Hasil analisis isi diharapkan dapat menganalisis pemanfaatan E-commerce dalam mempertahankan usaha di tengah resesi ekonomi.

\section{HASIL DAN PEMBAHASAN}

\section{Transformasi Bisnis dari Sistem Konvensional ke Sistem Online}

Pelaku usaha khususnya dalam sektor usaha kecil maupun UMKM sangat mengandalkan interaksi secara langsung atau dikenal dengan direct selling. Hal ini menjadi andalan sektor tersebut yang juga telah terbukti membuatnya bertahan ditengah krisis ekonomi 1998. Akan tetapi pelaku usaha dengan sistem konvensional lama-kelamaan semakin ditinggalkan konsumennya karena tidak lagi sesuai dengan tuntutan keadaan. Transformasi bisnis dari sistem konvensional ke media online telah berlangsung secara perlahan sejak internet mulai diakses dengan mudah di Indonesia namun tidak dapat berlangsung begitu saja mengingat banyaknya perangkat dan perlengkapan yang harus dipersiapkan agar dapat memberikan layanan yang baik meskipun secara virtual. Pelaku usaha harus memiliki akun media sosial maupun ecommerce sebagai langkah awal agar memberikan kemudahan akses bagi pelanggan untuk melakukan penelusuran, melihat katalog produk, hingga melakukan pemesanan secara online (Rofiq et al, 2020). Pelaku usaha perlu memelihara toko online atau website usaha dengan baik agar performa toko tetap terjaga. Adapun untuk melengkapi sistem layanan online yang disediakan maka dapat dilengkapi dengan keberadaan jasa antar. Transformasi sistem pemasaran dengan basis digital juga perlu dukungan dari mitra usaha, sehingga membangun relasi perlu dilakukan dengan baik. 
Transformasi sistem pemasaran dan kegiatan transaksi sejatinya menyesuaikan dengan tuntutan perubahan gaya hidup dan pola pikir masyarakat. Hal ini harus dimanfaatkan dengan baik oleh produsen agar secara konsisten mampu menyediakan konten dan informasi terbarukan mengenai produk yang dijual. Hal ini semata dilakukan agar mempertahankan konsumen atau memperluas pasar konsumen. Iklaniklan secara online dengan dukungan influencer juga menjadi salah satu alternatif agar toko online semakin dipercayai oleh para konsumen. Pelaku usaha juga memiliki kewajiban untuk melakukan riset pasar agar menyesuaikan dengan perkembangan usaha di lingkungan sekitarnya. Kejadian Covid-19 menjadi salah satu fenomena yang patut juga dianalisis oleh pelaku usaha mengingat memunculkan peluang besar bagi kesuburan bisnis online. Covid-19 menjadi faktor lingkungan luar yang telah menyebabkan penurunan pada aktivitas bisnis konvensional (offline) dan juga memacu kegiatan bisnis pada platform online (Taufik dan Ayuningtyas, 2020). Dengan demikian dapat disimpulkan bahwa transformasi sistem kegiatan transaksi harus diterima oleh berbagai pihak sesuai dengan tuntutan keadaan dan zaman terutama bagi usahausaha kecil dan UMKM yang ingin tetap mempertahankan eksistensi usahanya meskipun dihantam oleh berbagai tantangan akibat Covid-19. Digitalisasi menjadi keharusan agar semakin mengefektifkan pelayanan bagi pelanggan.

\section{Peran E-commerce bagi pelaku ekonomi}

Bagi pelaku usaha, E-commerce menjadi sarana jual-beli yang dapat meminimalisir pengeluaran biaya dan waktu. Hal ini karena pelaksanaan kerja lebih fleksibel daripada toko offline yang terpaku pada jam kerja tertentu. E-commerce bagi pelaku usaha juga berperan sebagai alternatif agar dapat meningkatkan performa penjualan produk usahanya. Keberadaan E-commerce sangat membantu pelaku usaha untuk memperluas jaringan usahanya, sehingga penjualan produk dapat menjangkau segmentasi pasar yang lebih luas tanpa mengkhawatirkan jarak dan waktu. E-commerce juga dapat dimanfaatkan sebagai media penghubung antara konsumen dan produsen, sehingga dapat menjadi masukan untuk meningkatkan kualitas produk di masa depan. Bisnis online bahkan tidak memerlukan lokasi khusus seperti halnya pada 
bisnis offline, sehingga produsen tidak perlu mengeluarkan biaya sewa tempat terlalu mahal karena bisnis dapat dilakukan dimana saja.

Bagi konsumen, E-commerce memberikan kemudahan untuk tidak perlu secara langsung mendatangi toko offline, sehingga tidak memerlukan biaya operasional cukup banyak untuk sekedar berbelanja. Keberadaan E-commerce lebih dapat menghemat waktu konsumen dengan beralih ke online shopping. E-commerce juga memfasilitasi komunikasi bagi konsumen kepada penjual secara online untuk menanyakan seputar produk yang dijual. Namun demikian, E-commerce bagi konsumen juga memungkinkan timbulnya kerugian akibat merk yang tidak jelas, produk yang tidak sesuai dengan gambar yang ditampilkan, hingga terjadinya penipuan seperti barang tidak dikirimkan (Sudaryono et al, 2020).

\section{Perkembangan E-commerce di masa pandemi}

E-commerce telah mengalami perubahan drastis akibat virus Covid-19 bahkan terjadi secara global. Pandemi Covid-19 telah mengubah perilaku manusia, cara hidup, hingga sifat perdagangan. Covid-19 memiliki pengaruh lebih luas mengingat dapat merubah sifat bisnis diseluruh dunia. Penelitian Bhatti et al (2020) menjelaskan bahwa $52 \%$ konsumen menghindari berbelanja secara fisik selama pandemi khususnya di area yang padat. Adapun 36\% diantaranya menyatakan bahwa mereka menghindari berbelanja secara langsung sampai memperoleh vaksin Covid-19. Hal inilah yang kemudian menyebabkan aktivitas penjualan diseluruh E-commerce mengalami peningkatan sebab orang-orang enggan keluar rumah dan menjaga jarak sosial.

Keunggulan teknologi dalam hal ini adalah penggunaan aplikasiaplikasi digital seperti E-commerce sehingga dapat mempertahankan kualitas dan kelangsungan hidup usaha baik saat pandemi hingga setelah pandemi. Hal ini wajar mengingat pembiasaan masyarakat untuk kembali pada situasi normal tentu memerlukan waktu yang tidak sebentar. Adapun dalam kurun waktu tersebut maka pelaku usaha perlu memikirkan strategi agar tetap bertahan. Ketidaksiapan pelaku usaha dalam menerima perubahan dalam lingkungan tentu akan sangat menyulitkan proses transformasi digital. Hal inilah yang membuat pelaku usaha gagal bertahan di masa pandemi. 
E-commerce akan memperoleh kontrol lebih besar atas pasar, sehingga banyak bisnis yang akan tergabung dengan platform-platform digital dalam rangka memperluas cakrawala bisnis (Mohamad et al, 2020). Hal ini menunjukkan bahwa E-commerce akan terus berkembang dan dibutuhkan seiring dengan perkembangan kebutuhan dunia digital. Jumlah transaksi perdagangan di E-commerce dicatat oleh Bank Indonesia mengalami peningkatan hampir dua kali lipat akibat Virus Covid-19 dengan nilai transaksi sebanyak 80 juta pada tahun 2019 meningkat menjadi 140 juta transaksi per agustus 2020 (CNN.com). Berikut disajikan rata-rata kunjungan pada web E-commerce di Indonesia per kuartal II 2020.

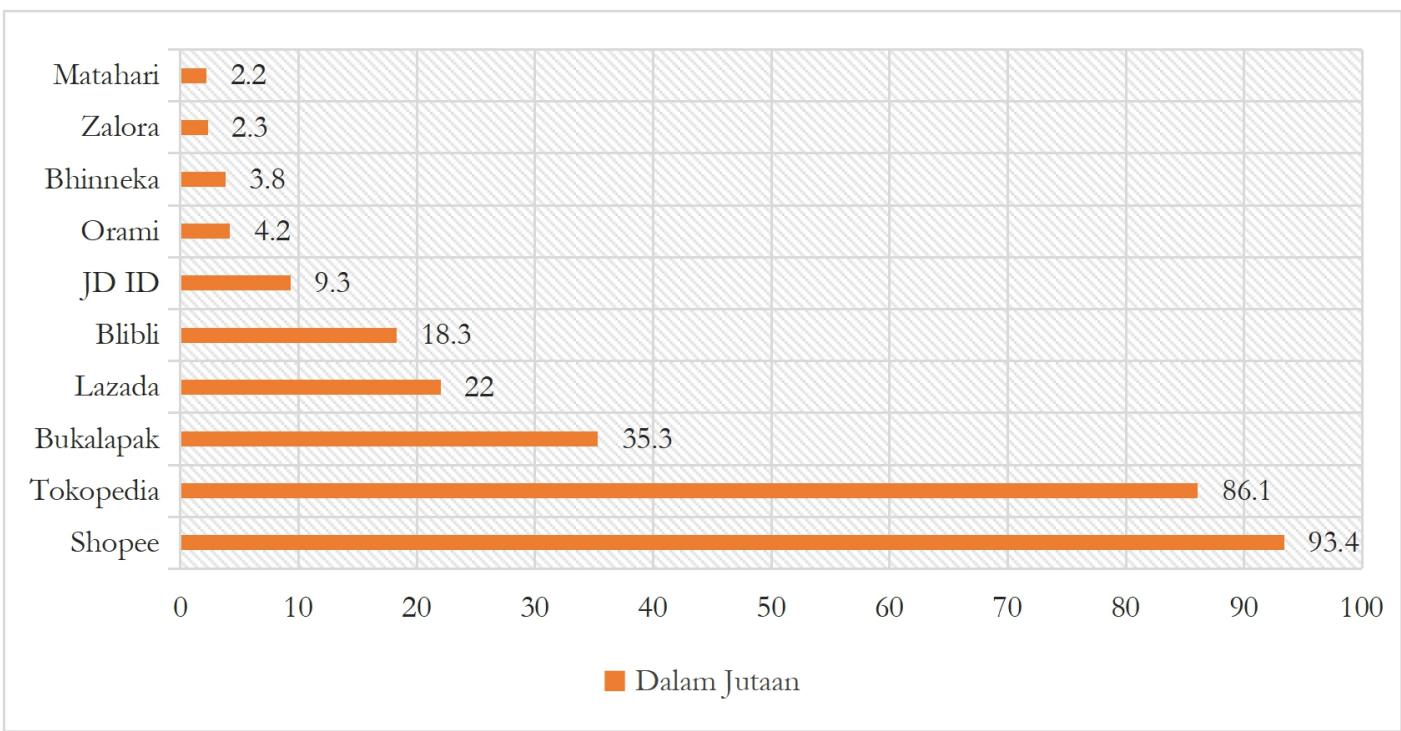

Sumber: databoks.katadata.co.id

Gambar 4. Rata-rata kunjungan web E-commerce bulanan Kuartal II 2020

Data di atas menunjukkan bahwa hampir sebagian besar masyarakat Indonesia yang dapat mengakses internet juga menggunakan E-commerce dalam menunjang aktivitas belanja sehari-hari. E-commerce telah menggeser gaya hidup yang bergantung pada toko-toko fisik (offline). Adapun di Indonesia terdapat empat E-commerce raksasa yang menguasai pasar online Indonesia, yaitu Shopee, Tokopedia, Bukalapak, dan Lazada. Platform Shopee bahkan menjadi yang penguasa pasar terbesar di Asia Tenggara. Platform digital tersebut memang berasal dari luar Indonesia, yakni Singapura namun demikian sejak didirikan pada 
2015 Shopee telah berhasil menarik pengguna dalam waktu promosi yang singkat bahkan mengalahkan para pesaing terdahulunya. Kemudahan akses barang bahkan hingga ke luar negeri inilah yang menjadi nilai lebih berbelanja secara online. Nilai order barang di marketplace yang lebih murah daripada membeli barang impor dengan sistem biasa membuat platform digital semakin diminati. Adapun di masa pandemi dari seluruh platform digital telah melonjak hingga 38,3\%, bahkan hal ini semakin membuat semua bisnis digital berlomba-lomba menggandeng brand ambassador terkenal. Persaingan E-commerce di Indonesia semakin ketat mengingat ketergantungan masyarakat di masa pandemi terhadap bisnis tersebut juga meningkat, sehingga hal ini dipandang sebagai peluang usaha bagi pengelola platform digital dan pelaku usaha pengguna platform digital.

Peningkatan pengguna E-commerce di masa pandemi pada dasarnya juga didukung oleh banyaknya promosi yang ditawarkan. Tawaran bebas ongkos kirim hingga cashback uang menjadi hal yang cukup menarik pengguna berbelanja pada platform digital. Hal ini tentu sangat membantu penjual tetap memperkenalkan produknya hingga menjual meskipun tidak ada interaksi secara langsung. Pembeli juga sangat terbantu karena memperoleh produk dengan tidak harus mengeluarkan biaya ongkos untuk bepergian. Kemudahan dari dua sisi tersebut menjadi sumber keuntungan bagi penyedia platform digital untuk tumbuh subur di Indonesia, mengingat jumlah penduduk yang padat dan konsumtif semakin mendorong pertumbuhan platform digital di Indonesia. Masa pandemi juga menjadi peluang bagi pertumbuhan $e$ commerce, sebab beberapa bisnis mengalami pertumbuhan pesat saat yang lain sedang berjuang. Adapun bisnis tersebut merupakan bisnis berbasis internet, seperti terkait hiburan online, pengiriman makanan, belanja online, pendidikan online, dan penyelesaian pekerjaan jarak jauh (Donthu dan Gustafsson, 2020).

\section{Peran E-commerce Terhadap Industri Usaha di masa Resesi Ekonomi}

Perkembangan layanan platform digital cukup terpengaruh dengan adanya perkembangan teknologi 4.0. Inovasi-inovasi yang dijalankan bisnis-bisnis online menjadi perangkat utama agar dapat bersaing dengan pesaingnya. Adapun inovasi-inovasi yang 
dikembangkan turut berkontribusi pada penyelesaian permasalahan dan kebutuhan masyarakat. Bisnis online berperan dalam memberdayakan dan meningkatkan kualitas perekonomian masyarakat melalui dukungan teknologi. Oleh karena itu, semakin mudah akses masyarakat dengan teknologi semakin memungkinkan juga masyarakat tersebut terbantu dengan fasilitas layanan platform digital dalam hal ini $e$-commerce.

E-commerce menjadi variasi yang muncul dalam transformasi digital untuk mendukung sektor bisnis. Prinsip efektivitas dan efisiensi menjadi hal utama dalam meningkatkan layanan perdagangan dengan basis digital. Perubahan paradigma perdagangan ini juga mengikuti perubahan pola perilaku konsumen, sehingga pendekatan digital mutlak diperlukan bagi bisnis yang ingin tetap bertahan dalam perekonomian. Hal ini menjadi peluang bagi para penyedia layanan E-commerce untuk menghadirkan inovasi layanan sesuai dengan kondisi masyarakat. Situasi pandemi yang membatasi interaksi fisik masyarakat mendorong berbagai E-commerce mengeluarkan berbagai macam produk untuk bersaing mempertahankan operasional usahanya. Dengan kata lain E-commerce menjadi satu-satunya bisnis yang justru tumbuh saat industri-industri lain mulai gulung tikar di masa pembatasan sosial hingga lockdown akibat pandemi. Hal ini ditegaskan dalam penelitian (Donthu dan Gustafsson, 2020) bahwa, "Another consequence of the lockdowns is the extreme increase Internet used and social media".

Penelitian tersebut menunjukkan bahwa pergeseran minat masyarakat dalam platform digital menjadi konsekuensi atas kebijakan pembatasan interaksi selama pandemi. Dengan kata lain keberadaan Ecommerce dengan segala platform digital mampu memfasilitasi interaksi masyarakat yang terbatas. E_commerce sebagai perwujudan dari ekonomi digital dalam skala makro juga memiliki kontribusi pada PDB Indonesia. Bahkan ekonomi digital juga membuka peluang kerja baru, sehingga menciptakan kemandirian berusaha. Semakin masyarakat mampu beradaptasi dengan perkembangan teknologi maka dapat mewujudkan kemandirian ekonomi Indonesia. Hal ini juga tidak membuat Indonesia menjadi market semata namun juga mengembangkan para pelaku usaha memasarkan produknya. Oleh karena itu, pemerintah selaku pemangku kepentingan harus mendorong tumbuhnya pelaku-pelaku usaha yang 
memanfaatkan platform digital sehingga pasar online juga tercipta dari dan oleh masyarakat Indonesia sendiri.

Adapun resesi ekonomi yang terjadi akibat pandemi Covid-19 dengan proyeksi -15 hingga $-2,9 \%$ harus diwaspadai termasuk oleh para pelaku usaha yang belum memanfaatkan E-commerce maupun sudah memanfaatkan e-commerce. Hal ini dikarenakan mayoritas investor $E$ commerce berasal dari luar negeri. Apabila resesi terjadi maka dapat memengaruhi finansial e-commerce, seperti berkurangnya promo-promo yang ditawarkan karena modal di-hold terlebih dahulu oleh investor. Hal ini dapat memengaruhi suistainability e-commrce di Indonesia yang mana sudah memiliki pengguna cukup banyak. Padahal promo menjadi daya tarik tersendiri bagi masyarakat untuk beralih ke pasar online. Apabila promo berkurang maka memungkinkan berkurangnya minat transaksi masyarakat dengan e-commerce.

Namun demikian, E-commerce menjadi satu-satunya pilihan bertahan khususnya ditengah pandemi Covid-19. Adapun resesi tentunya akan memengaruhi semua sektor usaha termasuk didalamnya platform e-commerce itu sendiri. Pandemi Covid-19 meningkatkan niat beli konsumen terhadap platform E-commerce karena manfaat kesehatan dan keselamatan yang dirasakan lebih terjaga melalui perantara media daripada bertransaksi langsung dengan pengecer melalui sistem tradisional (Tran, 2020). Pengusaha dan para pelaku usaha kecil maupun UMKM tentunya sangat berharap agar E-commerce tetap bertahan, sehingga eksistensi usaha tetap terjaga. Pelaku usaha kecil dan UMKM yang dahulu sangat berpegang teguh pada interaksi langsung dalam menyelamatkan usahanya di masa krisis ekonomi harus mau bertransformasi memanfaatkan pasar daring yang difasilitasi oleh Ecommerce agar tetap memasarkan produknya. Hal ini didorong agar terjadi keseimbangan antara dua sisi, yakni konsumen dan produsen dalam skala lokal. Mengingat resesi dapat diperburuk dengan semakin menurunnya jumlah konsumsi masyarakat. Adapun penurunan konsumsi masyarakat dapat menurunkan omset penjualan pelaku usaha kecil maupun UMKM.

Keseimbangan produksi dan ekonomi atau terjaganya daya beli masyarakat menjadi dasar utama pertumbuhan ekonomi. Semakin rendah daya beli masyarakat semakin minus pertumbuhan ekonomi 
suatu negara. Dengan kata lain negara tersebut akan semakin terjebak dalam resesi berkepanjangan. Oleh karena itu, tingkat konsumsi masyarakat sangat berpengaruh terhadap pertumbuhan ekonomi negara, sehingga upaya-upaya dalam rangka meningkatkan daya beli masyarakat diperlukan agar tidak terjadi kelesuan ekonomi berkepanjangan. Pemanfaatan E-commerce dengan segala promosi yang ada perlu untuk dipertahankan bahkan ditingkatkan agar semakin menarik minat masyarakat berbelanja secara online saat toko-toko offline mulai sepi pengunjung. Hal ini diupayakan sedemikian rupa agar keseimbangan antara produksi dan konsumsi terjaga dan tidak memengaruhi siklus perekonomian suatu negara. Apabila produksi yang dihasilkan tidak tersalurkan kepada konsumen dalam jangka waktu yang cukup lama maka akan menyebabkan penumpukan persediaan barang yang mana akan memengaruhi siklus produksi selanjutnya. Akibatnya banyak tenaga kerja yang dirumahkan hingga di PHK, sehingga hal ini menimbulkan banyak pengangguran dan peningkatan angka kemiskinan. Dengan demikian maka keberadaan E-commerce dalam siklus perekonomian terutama dalam siklus kelangsungan usaha sangat penting. E-commerce digunakan untuk berbagi informasi bisnis, mengelola jaringan bisnis, dan transaksi bisnis (Oven \& Hicintuka, 2020).

E-commerce mampu mendorong kemandirian berusaha bagi pelaku-pelaku usaha kecil hingga UMKM untuk tetap mempertahankan kegiatan usaha terutama dalam menghadapi resesi ekonomi. E-commerce juga memfasilitasi konsumen agar tetap menjaga daya belinya dengan minimalisasi biaya ongkos. Hubungan yang saling terkait antara pelaku usaha dan konsumen diintermediasi dengan keberadaan E-commerce sebagai perwujudan pasar online. Pergeseran paradigma pasar di Indonesia harus diadaptasi dengan baik agar menguntungkan baik penyedia layanan e-commerce, pelaku usaha, hingga konsumen. Pemerintah selaku pemangku kebijakan juga harus memberikan payung hukum yang tegas atas penyelenggaraan pasar online tersebut agar tidak muncul pelanggaran-pelanggaran hingga penipuan yang merugikan. Ecommerce juga memberikan kesempatan bagi Indonesia untuk tidak sekedar menjadi market namun juga sebagai penjual, sehingga produkproduk Indonesia juga dapat dikenal di negara lain. Hal ini juga menjadi 
salah satu alternatif bagi peningkatan ekspor yang sempat menurun saat pandemi Covid-19.

\section{SIMPULAN}

Pembatasan interaksi dan ketakutan atas pandemi covid19 menyebabkan penurunan pada aktivitas bisnis dengan sistem konvensional (toko fisik). Adapun sebaliknya terjadi peningkatan aktivitas pada bisnis online yang transaksinya dilakukan secara virtual. Sektor usaha kecil dan UMKM cukup terdampak dengan pandemi Covid-19 karena secara umum masih bergantung pada sistem konvensional. Pelaku usaha yang cenderung tidak beradaptasi dengan pergeseran perkembangan tersebut mengalami kemunduran hingga berujung gulung tikar. Adapun saat perekonomian diujung resesi maka pelaku usaha perlu mewaspadai berbagai hal mengingat investor perusahaan-perusahaan E-commerce berasal dari luar negeri yang kemungkinan akan menahan modalnya jika resesi berkepanjangan benar terjadi. E-commerce menjadi salah satu alternatif terbaik agar mendorong kemandirian berusaha terutama saat menghadapi resesi ekonomi. Ecommerce menjadi perwujudan pasar online mengingat tidak diperbolehkannya berkerumun di tempat-tempat umum. Bagi produsen atau penjual, E-commerce menjadi lapak yang baik agar tetap mempertahankan kegiatannya usahanya. Adapun bagi kosumen, Ecommerce menjadi tempat untuk tetap menjaga daya beli. Kegiatan transaksi yang tetap terjaga inilah yang dapat mendorong pertumbuhan ekonomi agar keluar dari jurang resesi.

Tren peningkatan pengguna E-commerce selama pandemi terbukti telah meningkat secara drastis. Saat ini transformasi bisnis dari sistem konvensional ke media online sedang berlangsung secara bertahap, terutama sejak internet dengan mudah mulai bisa diakses di Indonesia. Namun transformasi bisnis tersebut mesti ditunjang oleh perangkat dan perlengkapan digital yang dapat memberikan layanan virtual bagi para pelaku usaha secara komprehensif. Untuk itu diharapkan para pelaku usaha dapat mentransformasikan bisnisnya melalui media sosial agar dapat mempertahankan usahanya, mendorong pertumbuhan ekonomi dan segera keluar dari jurang resesi dimasa pandemi. 


\section{DAFTAR PUSTAKA}

Badan Pusat Statistik, Statistik E-commerce 2019, diakses pada 20 Oktober 2020 pada laman https:/ / www.bps.go.id

Badan Pusat Statistik, 2020 diakses pada 20 Oktober 2020 pada laman https://bps.go.id

Bhatti, Anam., Hamza Akram, Hafiz Muhammad Basit, dkk, E-commerce trends during COVID-19 Pandemic, International Journal of Future Generation Communication and Networking, Vol. 13, No. 2, 1449-1452

CNN Indonesia, 2020. Transaksi E-Cmmerce Naik Nyaris Dua Kali Lipat Saat Pandemi, diakses pada 21 Oktober 2020 pada laman https://m.cnnindonesia.com/ekonomi/2020102193353-925612342/transaksi-e-commerce-naik-nyaris-dua-kali-lipat-saatpandemi

Damuri, Yose Rizal dan Fajar B Hirawan, 2020. Mengukur Dampak COVID-19 pada Pertumbuhan Ekonomi dan Perdagangan Indonesia 2020. CSIS Commentaries DMRU-015.

Databoks.katadata.co.id, 2020. Peta Persaingan E-commerce Indonesia Pada Kuartal II 2020, diakses 21 Oktober 2020 pada laman https://databoks.katadata.co.id/datapublish/2020/01/21/ petapersaingan-e-commerce-Indonesia-pada-kuartal-ii-2020

Databoks.katadata.co.id. diakses pada 21 Oktober 2020 pada laman https://databoks.katadata.co.id/datapublish/2020/10/08/ konsumen-beralih-beli-produk-non-makanan-di-e-commercesaat-pandemi-Covid-19

Donthu, Noveen dan Anders GUstafsson, 2020. Effects of COVID-19 on business and research, Journal of Business Research,; 117: 284-289

Kompas.com. Bappenas Prediksi Pengangguran Tahun ini Capai 11 Juta orang. 27 Agustus 2020. Diakses 19 Oktober 2020 di laman https://money.kompas.com/read/2020/08/27/190600626/bapp enas-prediksi-jumlah-pengangguran-tahun-ini-capai-11-jutaorang

Mohammad, Abdul Hadi., Anis Athirah Hamzah., dan Romana Ramli, Ecommerce Beyond the Pandemic Coronavirus: Click and Collect Food Ordering, IOP Conference Series: Materials Science and Enginering, 1-7

Oven, Helen dan Melissa Hicintuka, 2020. Covid-19 : How does it affect international E-commerce firms?, (Tesis Linnaeus University Swede,

Rofiq, et al, 2020. Transformasi Bisnis Kreatif Micro Enterpreneur Dalam Mempertahankan Omset Di Masa Covid-19, Seminar Nasional 
Manajemen, Ekonomi Dan Akuntasi Fakultas Ekonomi Dan Bisnis Unp Kediri, 489-497

Sudaryono, Efana Rahwanto, dan Ratna Komala, 2020. E-commerce Dorong Perekonomian Indonesia Selama Pandemi Covid-19 Sebagai Enterpreneur Modern Dan Pengaruhnya Terhadap Bisnis Ofline, Jurnal Manajemen Dan Bisnis (Jumanis) Vol:02 No : 01

Sukirno, S, 2006. Makroekonomi Teori Pengantar. Jakarta: Raja Grafindo Persada.

Tan, Lobel Trong Thuy, 2020. Managing the effectiveness of E-commerce platforms in a pandemic, Journal of Retailing and Consumer Services, 1-9 https://doi.org/10.1016/j.jretconser.2020.102287

Taufik dan Eka V Ayuningtyas, 2020. Dampak Pandemi Covid-19 Terhadap Bisnis Dan Eksistensi Platform Online, Jurnal Pengembangan Wiraswasta, Vol. 22 No. 01, 21-32 